\title{
THE STRUCTURE OF INDEPENDENT LEARNING IN HIGHER EDUCATION: STUDENTS' ATTITUDE
}

\author{
Vilma Žydžiūnaitė \\ Margarita Teresevičienė \\ Genutė Gedvilienè \\ Vytautas Magnus University, Kaunas, Lithuania
}

\begin{abstract}
The search for self-identity is a key determinant of postmodern society while correlating with the independent learning being conceptualized by the higher education students; it refers their intensions to express the 'self' and be identified. Most researchers have studied independent, self-directed, self-regulated and self-managed learning by paying attention to the different aspects covering learning styles, interactions, cognition, emotions, or volition, learning processes, metacognitive control system with the focus on students' ability to direct, regulate and manage their independent learning. However, there is no research with the intention to explore the structure of the independent learning in higher education. Research results showed that despite perception of the independent learning structure the achievement of its outcomes cannot be ensured.
\end{abstract}

Key words: higher education, independent learning, self-directed learning, self-managed learning, self-regulated learning.

\section{Introduction}

Students' independent or autonomous learning (IL) in higher education (HE) has been the subject of intense research for more than two decades. A conclusion that may be drawn from this large body of research is that IL is a complex human activity and one not easy to conceptualize by means of a simple model (Zeegers, 2007). The autonomy is seen as the level of student control of the planning, execution, and evaluation of his or her own coursework (Wallace, 2010). The IL in HE refers to the ability to take charge of one's own learning. It means the responsibility for all the decisions concerning all aspects of this learning (Chan, 2010). The IL in most cases is used to mean the individual learning (Benson, 2001, 2002; Healey, 2007; Zeegers, 2007; Chan, 2010; Stockdale \& Brockett, 2011), indeed, as a term in research literature it is also used with the meaning of 'autonomous learning'; in this article the terms such as 'independent' and 'autonomous' will cover the same meaning of the IL.

Learner's autonomy and self-identity interface with a student taking greater control over the content and methods of learning presupposing individual's positive attitude towards the purpose and process of learning. The learner is perceived as a decision-maker who has or will develop the capacity for choosing from among available tools and resources to create what is needed for the task in hand (Chan, 2010). The individual responsibility towards learning is encapsulated in self-regulated learning (SRL) and the unsupervised or the IL is connected to self-acquired knowledge (Hiemstra, 2004), while the independent learner is related to self-managed learning (SML). 
To summarize, most researchers have studied the IL, the SDL, the SRL and the SML by focusing on the learning styles or knowledge strategies, interactions, cognition, emotions, volition or affection with the focus on students' ability to direct, regulate and manage their IL in order to capture effective IL strategies or types. Most of the research studies were based on the searching for the learning processes and metacognitive control systems. But there is no research internationally or nationally conducted with the intention to study the structure of the IL involving the SDL, the SRL and the SML.

The aim of the research refers to the description of the IL structure for the students representing higher education study programmes. Research focuses on the following research question: what components of the SDL, the SRL and the SML are significant to the students representing higher education study programmes in the IL?

\section{Reflection on learning types in independent learning}

Researchers have associated independence or autonomy with self-direction (Benson, 2001), motivation related to self-management (Harrison 2000), and self-regulation (Paris \& Paris, 2001) in learning.

The SDL can be described as intentional and self-planned learning, where individual is responsible for and in control of the learning (Roberson \& Merriam, 2005). The learning strategies, phases of the learning process, the content, the learner, and the environmental factors in the context must be all taken into account in mapping the process of SDL (Hiemstra, 2004; Hoban \& Hoban, 2004). The goals of the SDL (Merriam, 2001) are related to the development of learner's capacity to be self-directed; fostering transformational learning which posits critical reflection; the promotion of emancipatory learning and social action.

The SRL involves students' ability to be active participants in their own learning (Zimmerman, 2001; Cassidy, 2011). The SRL emphasizes autonomy and control by the individual who monitors, directs, and regulates actions toward goals of information acquisition, expanding expertise, and selfimprovement (Paris \& Paris, 2001). Goals that guide plans and behaviour, volition to enact them and feelings of self-efficacy that follow task completion are the motivational accompaniments of the SRL (Pintrich, 2000; Schunk \& Ertmer, 2000; Patrick \& Middleton, 2002).

Key values that underpin the SML are the following (O'Hara et al., 2004): empowerment, learning and facilitative management of learning. Expectations of self-management in educational settings reflect the increasing use of the SML in various environments (Lawler, 1998). The effective learner is seen as embodying a strong sense of self, intrinsic motivation, personal control and responsibility, high self-perceptions of competence and self-esteem (O'Hara et al., 2004). The self-managing learner is one who is self-aware, capable of 
exercising choice in relation to needs, of taking an active self-directing role in furthering his or her own learning and development (Harrison, 2000).

\section{Methodology}

In order to conduct the study a survey-based design was chosen. In surveys the subjects respond to a series of questions posed by the researchers. The content of the self-report survey is essentially limited only by the extent to which research participants are willing to report on the topic (Polit et al., 2001).

Sample. In the research proposal the survey covering $1620 \mathrm{BA}$ students $\left(2^{\text {nd }}, 3^{\text {rd }}\right.$ and $4^{\text {th }}$ study year) was foreseen. The sample scope was statistically calculated to represent the planned project research population with $1 \%$ standard error and $99 \%$ confidence level. The required sample scope estimated by power analysis included 1476 subjects. The sampling included the representatives referring to all study fields. The respondents were 1487 students representing HE study programmes at $10 \mathrm{HE}$ schools of Lithuania. The research data indicates the biggest percentage of research participants representing the social sciences (44\%) and biomedicine (26\%). The sample also consists of the students representing humanities $(11 \%)$, technologies $(8 \%)$, arts $(7 \%)$ and physical sciences $(4 \%)$. The research team tried to approximate the sample composition according to the popularity of the study field among school graduates in the years 2010 and 2011. The quota unit was chosen because the research participants were representatives of the $2^{\text {nd }}, 3^{\text {rd }}$ and $4^{\text {th }}$ study years. Specifically in 2010 and 2011 most of them entered higher education schools (universities and colleges). This data indicates that namely 2010 and 2011 school graduates preferred social sciences and biomedicine related study programmes to humanities, arts or physical sciences related study programmes. The sample was composed of $747(50.24 \%)$ university students and $740(49.76 \%)$ college students. Approximately, half of the sample $(46 \%)$ represented $2^{\text {nd }}$ year BA students, meanwhile BA students from $3^{\text {rd }}(27 \%)$ and $4^{\text {th }}(27 \%)$ were distributed equally.

Methods. The response rate was $91.79 \%$. SPSS 16.0 was used to process the data. The level of statistical significance set for the analysis of the data was $\alpha=0.05$. Factor analysis was used to study the inter-relationships among the variables with an effort to find a new set of factors (Bracey, 2006) regarding the SDL, the SRL and the SML separately.

Tool. The original questionnaire on $I L$ in $H E$ was used (C) Zydziunaite et al., 2011). The tool consisted of 86 questions in total. The content parts of the tool covered the background information (4 open-ended questions), the SDL (38 items), the SRL (24 items) and the SML (20 items). The Cronbach's $\alpha$ values were as follows: the SDL Cronbach's $\alpha=0.947$; the SRL Cronbach's $\alpha=0.945$; the SML Cronbach's $\alpha=0.909(P<0.000)$. The responses to 82 questions being 
formulated as the sentence-type items were measured on a Likert-type scale ranging from 1 (totally disagree) to 5 (totally agree).

Ethics. The ethical statement was provided by the Board of Vytautas Magnus University (26/08/2012, Protocol No. 9) confirming the study to be ethically acceptable and therefore conductive. The questionnaire was voluntarily and anonymously answered with no possibility for the research participants to be identified.

\section{Components of independent learning as manifestation of students' searching for self-identity}

Results represent only statistically meaningful factors (consisting of at least three factors with $<0.6)$ and the statistically meaningful items within it $(<0.6)$.

The $\boldsymbol{S D L}$ represents the model integrating three factors, though only two factors are statistically meaningful. Therefore, only two aspects are important for the students and they are revealed by the two factors: development of students' creativity through self-education of generic social and communication skills $\left(1^{\text {st }}\right.$ factor) and advantage of open-minded teacher-consultant role ( $2^{\text {nd }}$ factor $)$.

Table 2

Factor analysis of self-directed learning: rotated component matrix

\begin{tabular}{|c|c|}
\hline Content of factors within the components & $\begin{array}{l}\text { Factor } \\
\text { weight }\end{array}$ \\
\hline \multicolumn{2}{|c|}{$\begin{array}{l}\text { 1st: Development of students' creativity through self-education of generic social } \\
\text { and communication skills }\end{array}$} \\
\hline I enrich personal linguistic vocabulary & 0.637 \\
\hline I develop distinct skills being applied in the decision-making process at work & 0.630 \\
\hline I learn to communicate with others in variety of forms & 0.629 \\
\hline I learn to communicate orally in various situations & 0.612 \\
\hline I learn to keep to the agreements and rules & 0.610 \\
\hline Independent learning inspires me to be active & 0.609 \\
\hline $\begin{array}{l}\text { I learn to use the on-line information systematically by evaluating its } \\
\text { relevance }\end{array}$ & 0.602 \\
\hline I am becoming creative & 0.601 \\
\hline \multicolumn{2}{|l|}{ 2nd factor: The advantage of open-minded teacher-consultant role } \\
\hline Feedback from the teacher is of great importance for me & 0.674 \\
\hline Access to the teacher's consultations is of great importance for me & 0.650 \\
\hline Ineed the discussions with the teachers & 0.632 \\
\hline
\end{tabular}

$*$ KMO and Barlett test: Kaiser-Meyer-Olkin sample adequacy measure $=0.898388656$; Barlett Sfericity test, approx. Chi-square $=5955.983135 ; \mathrm{df}=666 ;$ Sig. $=0$.

The $\boldsymbol{S R \boldsymbol { L }}$ represents the model integrating five factors and only two factors among five are indeed statistically significant. The students have underlined the importance of responsibility by formulating the arguments and presenting them to the society, as well as perceived advantage of the assignments easily applicable in the professional activity. 
Factor analysis of self-regulated learning: rotated component matrix

\begin{tabular}{|c|c|}
\hline Content of factors within the components & $\begin{array}{l}\text { Factor } \\
\text { weight }\end{array}$ \\
\hline \multicolumn{2}{|l|}{ 1st factor: LIABLE FORMULATION OF ARGUMENTS } \\
\hline I learn formulating arguments according to the assignment given & 0.692 \\
\hline I take responsibility presenting personal thoughts and ideas to the society & 0.684 \\
\hline $\begin{array}{l}\text { I listen attentively to thoughts and ideas expressed by teachers and students } \\
\text { colleagues }\end{array}$ & 0.632 \\
\hline I acknowledge the variety of opinions, though I form my personal one & 0.607 \\
\hline \multicolumn{2}{|c|}{$\begin{array}{l}\text { 2nd factor: PERCEIVED ADVANTAGE OF PURPOSEFUL ASSIGNMENT FOR } \\
\text { PROFESSION }\end{array}$} \\
\hline I perceive the advantage of assignment for my professional activity & 0.682 \\
\hline I know the aims of performed assignments & 0.609 \\
\hline I reflect on the learning outcomes of studied materials & 0.605 \\
\hline
\end{tabular}

$* \mathrm{KMO}$ and Barlett test: Kaiser-Meyer-Olkin sample adequacy measure $=0.872879562$; Barlett Sfericity test, approx. Chi-square $=2207.398536 ; \mathrm{df}=276 ;$ Sig. $=7.897 \mathrm{E}-298$.

The $\boldsymbol{S M L}$ represents the model covering four factors. Only one factor in the model presented is statistically meaningful.

Table 4

Factor analysis of self-managed learning: rotated component matrix

\begin{tabular}{|c|c|}
\hline Content of factors within the components & $\begin{array}{l}\text { Factor } \\
\text { weight }\end{array}$ \\
\hline \multicolumn{2}{|c|}{$\begin{array}{l}\text { 1st factor: INFORMATION MANAGEMENT FOR GIVING MEANING TO THE } \\
\text { LEARNING EXPERIENCES }\end{array}$} \\
\hline $\begin{array}{l}\text { I learn the steps of the research process with information searching, } \\
\text { systematization, analysis and summary }\end{array}$ & 0.705 \\
\hline $\begin{array}{l}\text { I learn to prepare presentations and reports being oriented towards learning } \\
\text { assignment }\end{array}$ & 0.632 \\
\hline My previous learning experience helps to understand the learning materials & 0.626 \\
\hline
\end{tabular}

Results reveal the students' appreciation to work with the information. The students evaluate positively the acquired learning experiences that are premises to manage effectively the information.

\section{Discussion}

The research participants have noted that referring to the IL which incorporates the SDL, the SRL and the SML, the most meaningful components influencing motivated and meaningful IL could be the following: i) effectiveness of the teachers' consultations; and ii) the assignments, which develop creativeness as they are useful for the professional activity, because empower information management, stimulate reflection on the learning experiences, and mutual cooperation with others by sharing the variety of ideas. 
Specifics of the independent learning: themes of statistically significant factors

\begin{tabular}{|l|l|l|}
\hline \multicolumn{1}{|c|}{ Self-directed learning } & \multicolumn{1}{|c|}{ Self-regulated learning } & Self-managed learning \\
\hline $\begin{array}{l}\text { Development of the students' } \\
\text { creativity through self- } \\
\text { education of generic social and } \\
\text { communication skills }\end{array}$ & $\begin{array}{l}\text { Responsibility by } \\
\text { formulating the arguments }\end{array}$ & $\begin{array}{l}\text { Information management } \\
\text { for giving meaning to } \\
\text { learning experiences }\end{array}$ \\
\cline { 1 - 2 } $\begin{array}{l}\text { The advantage of the open- } \\
\text { minded teacher-consultant role }\end{array}$ & $\begin{array}{l}\text { Perceived advantage of } \\
\text { purposeful assignments for } \\
\text { professional activities }\end{array}$ & \\
\hline
\end{tabular}

Results indicate that one of the essential components in the SDL refers to the satisfaction of the students regarding the enrichment of personal linguistic vocabulary. This could be interpreted as the self-education experiences in the SDL since students should read a lot of various literature resources while learning independently: if they perceive the value of their studies, consequently, they are motivated to study deeply and meaningfully. These results corroborate the ideas of Bolliger \& Wasilik (2009) stating that the student's satisfaction depends on their perceived value of educational experiences. Wallace (2010) states that students enjoy leading the discussion and learn content better when they are the discussion leaders. Our research results confirm this idea: the students develop and improve social and communication skills while learning independently. The presented research findings point out that applying the IL with the reference to the components of the SDL, students become more creative and socially active, develop critical thinking through discussions, learn to keep to the rules and maintain responsibly while working with the information, understand the value of multiculturalism, etc. The correlations could be drawn comparing this context to the ideas of Stockdale \& Brockett (2011) accentuating that the self-direction in learning is viewed both as instructional method processes and personality characteristics of the individual learner. Both components operating within the learner's social context contribute to the outcome of the self-direction in learning.

The personal control of the environment and choices of one's actions are related to construct of the self-regulated learning (Stockdale \& Brockett, 2011). This perspective is related to our research results regarding the SRL as the students highlighted the learnt responsibility to formulate arguments when assignments are constructed by the teachers in the way that students should present their ideas to the colleagues and the society with the respect and responsibility. From this context is clear that the learners seem to study only what is essential for the assessment purposes and they confess that the assignments do influence their study behaviour (Kirkwood \& Price, 2006). Students have mentioned the importance of reflection on the IL through receiving the feedback from the teachers. This aspect is substantiated by Wallace (2010) stating that many 
subjects are difficult to learn on one's own without discussion, feedback, encouragement, or explanation from or with a knowledgeable other.

The learning is enhanced by the engagement in a community in which learners make sense of information and ideas (Wallace, 2010). Students in our research highlighted the importance of information management and the meaning of learning experiences as for Lizzio \& Wilson (2006) it is associated with the effective learner. These authors believe that the educational priority is not only to help students acquire skill, but also to help them develop the higher order capability of becoming effective learners. Our research results support this idea that in the SML the assignment, reflection and experiences are interrelated. It means, the assignments are not in status quo position and be designed and developed to take account of the situation and circumstances of independent learners (Kirkwood \& Price, 2006).

The issue with a construct of the IL being positioned at the junction of variety of research fields and with three other complex constructs such as the SDL, the SRL and the SML implies hypothesis that the researchers conceptualize terms and processes of the similar constructs differently. However, it is evident that the construct of the IL with the SDL, the SRL and the SML encapsulates the learning direction, regulation and management, as well as cognition of the self.

\section{Conclusion}

The construct of the IL is powerful while consisting of the structural components such as the SDL, the SRL and the SML which cannot be ignored. Knowing and perceiving the essence of these components becomes the strength of a student and a teacher, because they are considered to be a part of the successful IL allowing understanding how the IL achievements could be related to the self (motivation, cognition, affection, volition and emotion), learning environment, interactions, cooperation, ICT and other aspects.

Knowing the structure of the IL can enable the origin of new learning forms though cannot ensure that effective IL outcomes are achieved. Students and teachers need to recognize both the way for applying variety of methods, tools or technologies, and all the benefits in this regard. Students' attitudes about the value of various resources regarding the SDL, the SRL and the SML are related to whether or not those components are linked to the IL outcomes. In HE students are engaged in a constant task of negotiating meanings from lived and mediated learning experiences as they endeavour to construct and maintain their identity through the IL.

\section{Acknowledgements}

The study was supported by the Lithuanian Research Council (Agreement No. MIP111/2011). 
Proceeding of the International Scientifical Conference May $23^{\text {th }}-24^{\text {th }}, 2014$

Volume I

\section{References}

1. Benson, P. (2001). Teaching and researching autonomy in language learning. Harlow, England: Pearson.

2. Benson, P. (2002). Rethinking the relationship of self-access and autonomy. Self-Access Language Learning, 5( 2): 3-7.

3. Bolliger D.U., Wasilik, O. (2009). Factors influencing faculty satisfaction with online teaching and learning in higher education. Distance Education, 30(1): 103-116.

4. Bracey, G.W. (2006). Reading Educational research: How to avoid getting statistically snookered. Portsmouth, NH: Heinemann.

5. Chan, V. (2010). Autonomous Language Learning: The teachers' perspectives. Teaching in Higher Education, 8(1): 33-54.

6. Harrison, R. (2000). Learner managed learning: managing to learn or learning to manage? International Journal of Lifelong Education, 19(4): 312-321.

7. Healey, D. (2007). Theory and research: Autonomy and language learning. In CALL environments: Research, practice and critical issues, eds. J. Egbert and E. Hanson-Smith. Alexandria, VA: TESOL. pp. 377 - 389

8. Hiemstra, R. (2004). Self-directed learning lexicon. International Journal of SelfDirected Learning, 1(2): 1-6.

9. Hoban, Sh., Hoban, G. (2004). Self-esteem, self-efficacy and self-directed learning attempting to undo the confusion. International Journal of Self-Directed Learning, 1(2): 7-25.

10. Lawler, E.E. (1998). Strategies for high performance organisations. San Francisco, CA: Jossey-Bass.

11. Lizzio, A., Wilson, K. (2006). Enhancing the effectiveness of self-managed learning groups: understanding students' choices and concerns. Studies in Higher Education, 31(6): 689-703.

12. Merriam, Sh.B. (2001). Andragogy and Self-Directed Learning: Pillars of Adult Learning Theory. In New Directions for Adult and Continuing Education, 89: 3-13. San Francisco, CA: Jossey-Bass Publishers.

13. O'Hara, S., Bourner, T., Webber, T. (2004). The practice of self-managed action learning. Action Learning: Research and Practice, 1(1): 29-42.

14. Polit, D.F, Beck, Ch.T., Hungler, B.P. (2001). Essentials of Nursing Research: Methods, Appraisal and Utilisation. Philadelphia: Lippincott.

15. Pintrich, P.R. (2000). The role of goal orientation in self-regulated learning. In Handbook of self-regulation, eds. M. Boekaerts, P. Pintrich, and M. Zeidner. New York: Academic. pp. 452-502.

16. Schunk, D.H., Ertmer, P.A. (2000). Self-regulation and academic learning: Self-efficacy enhancing interventions. In Handbook of self-regulation, eds. M. Boekaerts, P. Pintrich, and M. Zeidner. New York: Academic. pp. 631-649.

17. Stockdale, S.L., Brockett, R.G. (2011). Development of the PRO_SDLS: A Measure of Self-Direction in Learning Based on the Personal responsibility Orientation Model. Adult Education Quarterly, 61(2): 161-180.

18. Paris, S.G., Paris, A.H. (2001). Classroom Applications of Research on Self-Regulated Learning. Educational Psychologist 36(2): 89-101.

19. Patrick, H., Middleton, M.J. (2002). Turning the Kaleidoscope: What We See When SelfRegulated Learning is Viewed With a Qualitative Lens. Educational Psychologist, 37(1): 27-39.

20. Roberson, D.N., Merriam, Sh.B.M. (2005). The Self-Directed Learning process of Older, Rural Adults. Adult Education Quarterly, 55(4): 269-287. 
21. Wallace, R.M. (2010). Online Learning in Higher Education: a review of research on interactions among teachers and students. Education, Communication \& Information, 3(2): 241-280.

22. Zeegers, P. (2007). Student learning in higher education: path analysis of academic achievement in science. Higher Education Research \& Development, 23(1): 35-56.

23. Zimmerman, B.J., Schunk, D. (2001). Self-regulated learning and academic achievement. New York: Springer-Verlag.

$\begin{array}{ll}\text { Vilma Žydžiūnaitė } & \text { Department of Education, } \\ & \text { Vytautas Magnus University, } \\ & \text { K. Donelaičio str. 52-303, } \\ & \text { LT-44244, Kaunas, Lithuania } \\ & \text { E-mail: v.zydziunaite@kic.vdu.lt } \\ & \text { Department of Education, } \\ \text { Margarita Teresevičienė } & \text { Vytautas Magnus University, } \\ & \text { K. Donelaičio str. 52-303, } \\ & \text { LT-44244, Kaunas, Lithuania } \\ & \text { Department of Education, } \\ \text { Genutė Gedvilienė } & \text { Vytautas Magnus University, } \\ & \text { K. Donelaičio str. 52-303, } \\ & \text { LT-44244, Kaunas, Lithuania }\end{array}$

